\title{
Effects of psychological problems on surgical outcomes
}

\section{SUMMARY}

Surgeons are becoming aware that surgical outcomes are not only based on technical skills. The impact of psychological problems on outcomes must be studied from both the patient's and the health care provider's viewpoint. Psychological problems may affect up to $20 \%$ of the population, with almost half of them non-treated. Surgeons have to deal with a significant number of patients with psychological problems, which affect surgical outcomes changing how symptoms, results and side effects are interpreted. Surgeons also face psychological problems at a significant rate. Although there are no studies on the effect of chronic psychological problems of the surgeon on outcomes, in simulated scenarios, acute stress usually leads to worse performance. Some initiatives can be implemented to improve outcomes based on the effect of psychological problems.

KEYWORDS: surgery; treatment outcome; mental disorders; burnout, professional

\section{INTRODUCTION}

Surgeons are becoming aware that surgical outcomes are not only based on technical skills. Thus, current surgical literature is open to multidisciplinarity, perioperative care, analysis of surgical team cognition and non-technical skills, among others. The impact of psychological problems on outcomes is also noteworthy from both the patient's and the health care provider's viewpoint.

Effects of psychological problems on surgical outcomes - Patients

The first question to be answered is how many of our patients have psychological problems. A survey in a large metropolitan area showed a prevalence of minor psychiatric disorders (anxiety/depression) in $20 \%$ of the population'. This figure varies according to geographic location, age, and socioeconomic status, but remains close to the 15 to $20 \%$ rate $^{2-4}$. Moreover, a significant number of individuals have a non-diagnosed or non-treated status. In the US, the prevalence of mental disorder was $18 \%$ in 2016 , but only $43 \%$ received some treatment, according to the National Institute of Mental Health. Thus, surgeons have to deal with a significant number of patients with psychological problems.

The second question is how the patient's psychological problems affect surgical outcomes. First, they change how symptoms are interpreted. Psy- 
chological problems may lead to hypersensitivity and hypervigilance. These two conditions may be part of the clinical presentation of the psychological problem, but there is also a molecular relationship between mental disorders and pain modulation ${ }^{5}$. Second, they affect the way results are interpreted. Patients may suffer from the nocebo phenomenon, defined as when a patient experiences adverse side-effects that are not a direct result of the proposed treatment ${ }^{6}$. Side effects, even irrelevant symptoms, of operation may be disastrous, and persistent unrelated symptoms may prevent expectations from being fulfilled.

The deterioration of surgical outcomes due to psychological problems has been studied in functional surgical diseases such as gastroesophageal reflux disease (GERD). Velanovich et al. ${ }^{7}$ showed a decrease in satisfactory outcomes after a fundoplication from $95 \%$ to $11 \%$ in the presence of a psychiatric disorder. Outside the functional disorders in which a psychological problem could intuitively have more influence, psychological status also plays a role in the recovery from different types of operations in terms of pain perception, return to work, and quality of life ${ }^{8}$. Psychological problems seem to be detrimental even to oncological survival ${ }^{9}$.

\section{Effects of psychological problems on surgical outcomes - Surgeons}

If we ask the same question as we did for patients, of how many surgeons have psychological problems, the first thing that comes to most of our minds is the estimate that surgeons are the 5th career with the highest proportion of psychopaths ${ }^{10}$. Is this caused by a peculiar "surgical personality" or surgeons do have psychological problems in a higher proportion? The surgical personality does seem to exist. Surgeons have higher levels of conscientiousness, agreeableness, openness, and neuroticism than

FIGURE 1: IMPROVEMENT OF OUTCOMES BASED ON THE EFFECT OF PSYCHOLOGICAL PROBLEMS

\begin{tabular}{l|l} 
Patients & Surgeons \\
\hline $\begin{array}{l}\text { Minor psychiatric disorders } \\
\text { diagnosis (scores) }\end{array}$ & Care for personal wellness \\
\hline Long conversations & Search for mentors \\
\hline $\begin{array}{l}\text { Careful selection for proce- } \\
\text { dures }\end{array}$ & $\begin{array}{l}\text { Learn how to deal with errors and } \\
\text { adversities }\end{array}$ \\
\hline Multidisciplinary care & \\
\hline
\end{tabular}

non-surgeons ${ }^{11}$. Surgeons, however, are prone to psychological problems as well. Minor psychiatric disorders are diagnosed on $16-37 \%$ of surgeons ${ }^{12}$. Burnout is a serious problem that has been extensively studied. It is "a syndrome of emotional exhaustion and cynicism that occurs frequently among individuals who do people work of some kind"'s. Burnout among surgeons is increasing in incidence, with a rate of $53 \%$ in $2014^{13}$. The scenario keeps getting worse. Alcoholism among surgeons reaches $15 \%{ }^{14}$, and suicidal ideation ranges from $6 \%$ in the US to $18 \%$ in Italy ${ }^{15,16}$.

In regards to the second question, whether surgeons' psychological problems affect surgical outcomes is still debatable. Acute stress and stressors, such as sleep deprivation, certainly affect technical performance ${ }^{17}$. To the best of our knowledge, there are no dedicated studies on chronic psychological problems and surgical outcomes. Several studies, however, show that surgeons are profoundly affected by errors ${ }^{18}$.

A third question arises when one inquiry if it is possible to select better psychologically prepared surgeons. We asked past and present surgical residents in regards to attitudes, experiences during training, and professional expectations to find less professional satisfaction among the present residents ${ }^{19,20}$. The decreased satisfaction with work, which is characteristic of the generation $\mathrm{Y}^{21}$, may increase the level of burnout and probably of minor psychiatric disorders. Unfortunately, a good tool to select successful surgical residents is not yet available ${ }^{22}$.

\section{PREVENTION}

Some initiatives could improve outcomes based on the effect of psychological problems (Figure 1).

In regards to the patient's psychological problems, the use of scores or questionnaires to diagnose psychological problems is restricted by limitations of the available tools and ethical aspects. Nevertheless, long conversations are necessary to understand the expectations of patients concerning outcomes and to express possible side effects. Patients must be carefully selected for adequate procedures. Finally, multidisciplinary care is essential since surgeons usually are not good for handling patients with psychological problems.

From the surgeons' perspective, they must take good care of their wellness, search for mentors ${ }^{13}$, and learn how to deal with errors and adversities. In es- 
sence, they can do what they like but also need to like what they have to do and be resilient. Curiously, resilience was the theme of 3 presidential addresses from 3 different surgical societies ${ }^{23-25}$. In all 3, resilience was claimed as a desirable characteristic to excel in surgery.

\section{Conflict-of-interest statement}

\section{There are no conflicts of interest to report.}

Conference at the International Session "Non-technical skills for gastrointestinal surgeons" at the SSAT Annual Meeting, Washington, DC, June 2018.

\section{RESUMO}

Os cirurgiões atuais cada vez mais acreditam que o bom resultado das cirurgias não são frutos exclusivos de suas habilidades técnicas. O impacto dos fatores psicológicos nos resultados das cirurgias deve ser estudado do ponto de vista tanto dos pacientes quanto dos profissionais de saúde que os assistem. Os problemas psicológicos afetam mais de 20\% da população em geral, sendo que metade destes não recebe qualquer tratamento específico. Assim, os cirurgiões tratam de números cada vez mais significativos de pacientes com problemas psicológicos. Esses problemas psicológicos afetam o resultado, na medida em que alteram a percepção e interpretação dos sintomas, resultados e efeitos colaterais dos procedimentos. Por outro lado, os próprios cirurgiões têm apresentado taxas crescentes de afecções psicológicas. Embora não existam estudos que demonstrem o impacto dos problemas psicológicos crônicos dos cirurgiões na evolução dos pacientes, em cenários simulados, observa-se que o estresse agudo desencadeia um desempenho pior desses profissionais. Concluímos, dessa maneira, que medidas direcionadas à detecção e tratamento dos problemas psicológicos, tanto dos pacientes quanto da equipe de saúde, devam ser implementadas visando melhores resultados cirúrgicos.

PALAVRAS-CHAVE: Cirurgias. Prognóstico. Transtornos mentais. Esgotamento profissional.

\section{REFERENCES}

1. Andrade LH, Wang YP, Andreoni S, Silveira CM, Alexandrino-Silva C, Siu ER, Nishimura R, Anthony IC, Gattaz WF, Kessler RC, Viana MC. Mental disorders in megacities: findings from the São Paulo megacity mental health survey, Brazil. PLoS One. 2012;7(2):e31879. doi: 10.1371/journal. pone.0031879. Epub 2012 Feb 14.

2. Chavan BS, Das S, Garg R, Puri S, Banavaram AA. Prevalence of mental disorders in Punjab: Findings from National Mental Health Survey. Indian | Psychiatry. 2018 Jan-Mar;60(1):121-126. doi: 10.4103/psychiatry.Indian)Psychiatry_221_17.

3. Philipp |, Zeiler M, Waldherr K, Nitsch M, Dür W, Karwautz A, Wagner G. The Mental Health in Austrian Teenagers (MHAT)-Study: preliminary results from a pilot study. Neuropsychiatr. 2014;28(4):198-207. doi: 10.1007/ s40211-014-0131-9. Epub 2014 Nov 28.

4. Leung PW, Hung SF, Ho TP, Lee CC, Liu WS, Tang CP, Kwong SL. Prevalence of DSM-IV disorders in Chinese adolescents and the effects of an impairment criterion: a pilot community study in Hong Kong. Eur Child Adolesc Psychiatry. 2008 Oct;17(7):452-61. doi: 10.1007/s00787-0080687-7. Epub 2008 Apr 21.

5. Mayer EA, Craske M, Naliboff BD. Depression, anxiety, and the gastrointestinal system. J Clin Psychiatry. 2001;62 Suppl 8:28-36; discussion 37.

6. Velanovich $V$. Nonsurgical factors affecting symptomatic outcomes of antireflux surgery. Dis Esophagus. 2006;19(1):1-4

7. Velanovich V, Karmy-Jones R. Psychiatric disorders affect outcomes of antireflux operations for gastroesophageal reflux disease. Surg Endosc. 2001 Feb;15(2):171-5.

8. Aspari AR, Lakshman K. Effects of Pre-operative Psychological Status on Post-operative Recovery: A Prospective Study. World J Surg. 2018 lan;42(1):12-18.

9. Kim GM, Kim SJ, Song SK, Kim HR, Kang BD, Noh SH, Chung HC, Kim KR, Rha SY. Prevalence and prognostic implications of psychological distress in patients with gastric cancer. BMC Cancer. 2017 Apr 20;17(1):283. doi: 10.1186/s12885-017-3260-2

10. Dutton K. The wisdom of psychopaths: what saints, spies, and serial killers can teach us about success. Scientific American, New York. 2012

11. Whitaker M. The surgical personality: does it exist? Ann R Coll Surg Engl 2018 lan;100(1):72-77. doi: 10.1308/rcsann.2017.0200.

12. Oskrochi Y, Maruthappu M, Henriksson M, Davies AH, Shalhoub J. Beyond the body: A systematic review of the nonphysical effects of a surgica career. Surgery. 2016 Feb;159(2):650-64. doi: 10.1016/j.surg.2015.08.017. Epub 2015 Oct 1.

13. Patti MG, Schlottmann F, Sarr MG. The Problem of Burnout Among
Surgeons. JAMA Surg. 2018 May 1;153(5):403-404. doi: 10.1001/jamasurg.2018.0047.

14. Oreskovich MR, Kaups KL, Balch CM, Hanks |B, Satele D, Sloan |, Meredith C, Buhl A, Dyrbye LN, Shanafelt TD. Prevalence of alcohol use disorders among American surgeons. Arch Surg. 2012 Feb;147(2):168-74. doi: 10.1001/archsurg.2011.1481.

15. Shanafelt TD, Balch CM, Dyrbye L, Bechamps G, Russell T, Satele D Rummans T, Swartz K, Novotny PI, Sloan |, Oreskovich MR. Special report: suicidal ideation among American surgeons. Arch Surg. 2011 Jan;146(1):5462.

16. Wall M, Schenck-Gustafsson K, Minucci D, Sendén MG, Løvseth LT, Fridner A. Suicidal ideation among surgeons in Italy and Sweden - a cross-sectional study. BMC Psychol. 2014 Nov 29;2(1):53. doi: 10.1186/s40359-0140053-0. eCollection 2014

17. Hull L, Arora S, Aggarwal R, Darzi A, Vincent C, Sevdalis N. The impact of nontechnical skills on technical performance in surgery: a systematic review. I Am Coll Surg. 2012 Feb;214(2):214-30. doi: 10.1016/j.jamcollsurg.2011.10.016. Epub 2011 Dec 24.

18. Luu S, Leung SO, Moulton CA. When bad things happen to good surgeons: reactions to adverse events. Surg Clin North Am. 2012 Feb;92(1):153-61. doi: 10.1016/j.suc.2011.12.002. Epub 2011 Dec 27.

19. Herbella FA, Fuziy RA, Takassi GF, Dubecz A, Del Grande IC. Evaluation of training and professional expectations of surgery residents. Rev Col Bras Cir. 2011 Jul-Aug;38(4):280-4.

20. Lafraia FM, Herbella FA, KallufJR, Schlottman F, Patti M. Attitudes, experience during training and professional expectations in generation y surgical residents. Rev Assoc Med Bras in press

21. Herbella FA, Velanovich V. Observations on multi-generational interactions in academic surgical practice and education. Rev Assoc Med Bras in press

22. Gardner AK, Dunkin B). Evaluation of Validity Evidence for Personality, Emotional Intelligence, and Situational Judgment Tests to Identify Successful Residents. JAMA Surg. 2018 May 1;153(5):409-416. doi: 10.1001/ jamasurg.2017.5013.

23. Minter RM. Passion, integrity, resilience: core values to carry us forward. Surgery. 2018 May;163(5):996-1001. doi: 10.1016/j.surg.2017.12.006.

24. Kurek SJ Jr. EAST 2016 Presidential Address: Resilience. J Trauma Acute Care Surg. 2016 Jul;81(1):1-7. doi: 10.1097/TA.0000000000001095.

25. Vickers SM, Vickers AL. Lessons Learned from Mentors and Heroes on Leadership and Surgical Resilience. | Gastrointest Surg. 2017 |an;21(1):1-11. doi: 10.1007/s11605-016-3257-1. Epub 2016 Oct 17 